\section{APROTININ AND METHYLPREDNISOLONE EQUALLY BLUNT CARDIOPULMONARY BYPASS-INDUCED INFLAMMATION IN HUMANS}

Cardiopulmonary bypass induces an inflammatory state characterized by tumor necrosis factor- $\alpha$ release. Integrin $\mathrm{CD11b}$ is a neutrophil surface adhesive glycoprotein integrin that is rapidly and permanently unregulated by tumor necrosis factor- $\alpha$ exposure. The CD11b integrin is known to be the primary neutrophil integrin responsible for neutrophil lung and myocardial entrapment after cardiopulmonary bypass and subsequent reperfusion injury. Twenty-four adults admitted to the hospital for myocardial revascularization were equally randomized to one of three groups: group $A$ (control), group B (methylprednisolone before cardiopulmonary bypass), and group $\mathrm{C}$ (low-dose aprotinin protocol). Blood was collected at three times: (1) baseline, (2) 50 minutes of cardiopulmonary bypass duration, and (3) 30 minutes after cardiopulmonary bypass termination. Neutrophil CD11b integrin expression was measured by fluorescence-activated cell sorter analysis and plasma tumor necrosis factor- $\alpha$ levels measured by enzyme-linked immunosorbent assay. Group A demonstrated significant $(p<0.05)$ increases in CD11b expression at times 2 and 3 when results were compared with those of the same group baseline and with those of groups $B$ and $C$ at similar times. No significant changes were noted between groups $B$ and $C$ at any time. Group A demonstrated a significant $(p<0.05)$ increase in levels of tumor necrosis factor- $\alpha$ at time 3 when results were compared with those of the same group baseline and of groups $B$ and $C$ at the same time. No significant changes were noted between groups $B$ and $C$ at any time. These results demonstrate low-dose aprotinin has a similar antiinflammatory effect to that of methylprednisolone in blunting cardiopulmonary bypass-induced systemic tumor necrosis factor- $\alpha$ release and neutrophil integrin CD11b upregulation. (J THORAC CARDIOVASC SURG 1995;110:1658-62)

Gary E. Hill, MD, FCCM, ${ }^{\mathrm{a}, \mathrm{b}}$ Anselmo Alonso, MD, ${ }^{\mathrm{c}}$

John R. Spurzem, MD, ${ }^{\mathrm{b}}$ Alfred H. Stammers, MSA, CCP, ${ }^{\mathrm{d}}$ and Richard A. Robbins, MD, ${ }^{\mathrm{b}}$ Omaha, Neb.
C ardiopulmonary bypass (CPB) induces a state characterized by systemic endotoxin and tumor necrosis factor (TNF) release. ${ }^{1}$ Neutrophil integrin CD11b is rapidly ${ }^{2}$ and permanently ${ }^{3}$ upregulated by cytokines, including TNF, ${ }^{4}$ and is thought to be the primary neutrophil adhesive integrin responsible for

From the Departments of Internal Medicine, ${ }^{\mathrm{b}}$ Anesthesiology, ${ }^{\mathrm{a}}$ Surgery, ${ }^{\mathrm{c}}$ and Perfusion Sciences Education, ${ }^{\mathrm{d}}$ University of Nebraska Medical Center, Omaha, Neb.

Received for publication Feb. 28, 1995.

Accepted for publication April 6, 1995.

Address for reprints: Gary E. Hill, MD, FCCM, Department of Anesthesiology and Internal Medicine, University of Nebraska Medical Center, 600 S. 42 St., Box 984455, Omaha, NE 68198-4455.

Copyright (c) 1995 by Mosby-Year Book, Inc.

$0022-5223 / 95 \$ 5.00+0 \quad \mathbf{1 2} / \mathbf{1} / \mathbf{6 5 3 2 3}$ neutrophil organ entrapment, resulting in post-CPB reperfusion injury or lung ${ }^{5,6}$ and myocardium. ${ }^{7} \mathrm{Al}-$ though glucocorticoids are known to blunt TNF plasma levels $^{8}$ and neutrophil CD11b upregulation ${ }^{9}$ induced by CPB, the effect of aprotinin on these CPB-induced events has not previously been studied. Previous studies have demonstrated aprotinin to reduce the cardiovascular response to endotoxin in an animal mode ${ }^{10}$ and to blunt interleukin-6 release during $\mathrm{CPB},{ }^{11}$ suggesting aprotinin may have a modifying effect on CPB-induced cytokine release and subsequent neutrophil CD11b upregulation.

\section{Methods}

After Institutional Review Board approval and patient informed consent were obtained, 24 male patients sched- 
uled for elective aorta-coronary bypass were randomized equally to one of three groups: (1) a control group (group A), (2) a group that received methylprednisolone (1 gm intravenously) administered 5 minutes before CPB (group $B$ ), and (3) a group that received aprotinin, $140 \mathrm{mg}$ intravenously as a loading dose, $140 \mathrm{mg}$ in the pump prime and $35 \mathrm{mg} \cdot \mathrm{hr}^{-1}$ as an intravenous constant infusion until chest closure (group C).

On the morning of the operation, each patient was given morphine sulfate $(0.1 \mathrm{mg} / \mathrm{kg})$ and scopolamine $(0.2$ to $0.4 \mathrm{mg}$ ) intramuscularly before admission to the operating room. On arrival, a radial artery catheter, a right internal jugular vein pulmonary artery catheter, and largebore intravenous lines were placed. Standard anesthetic treatment consisting of fentanyl ( 75 to $100 \mu \mathrm{g} / \mathrm{kg}$ ) as a short intravenous infusion and pancuronium (0.1 to 0.2 $\mathrm{mg} / \mathrm{kg}$ ) was used. CPB was completed with a centrifugal pump (Medtronic Bio-Medicus, Inc., Eden Prairie, Minn.), hollow-fiber membrane oxygenator (Baxter Healthcare Corp., Irvine, Calif.) with arterial line filtration, and mild hypothermia $\left(32^{\circ} \mathrm{C}\right.$ core temperature). Perfusion flow rate and mean arterial pressure during CPB were maintained between 2.2 and $2.4 \mathrm{~L} \cdot \mathrm{min}^{-1} \cdot \mathrm{m}^{2-1}$ and 60 to $80 \mathrm{~mm} \mathrm{Hg}$, respectively. Myocardial preservation was achieved through both antegrade and retrograde administration of cold hyperkalemic blood ( 8 to 1 blood to crystalloid mixture) cardioplegic solution. A terminal dose of normothermic continuous cardioplegic solution was administered approximately 15 minutes before reperfusion. Anticoagulation in groups A and B was obtained by the administration of bovine lung heparin $(300 \mathrm{IU} / \mathrm{kg})$, and activated clotting times (ACTs) were maintained at greater than 480 seconds in all groups by the addition of heparin when necessary. Systemic anticoagulation in group $\mathrm{C}$ was achieved through the administration of bovine lung heparin $(400 \mathrm{U} / \mathrm{kg}$ ) to maintain kaolin-based ACTs greater than 600 seconds. At the termination of CPB protamine was administered in a ratio of $1.3 \mathrm{mg}$ for every $100 \mathrm{U}$ of total heparin administration, and efficacy was confirmed by the return of the ACT to baseline values.

Twenty milliliters of heparinized whole blood was drawn at three times: (1) baseline (after placement of the arterial and intravenous catheters but before anesthetic drug administration), (2) after 50 minutes of $\mathrm{CPB}$, and (3) 30 minutes after termination of CPB. No patient received blood products during periods 1 through 3 .

The blood samples were immediately taken to the laboratory. Laboratory personnel were blinded as to which group of the study each patient was assigned. Dextran (Pharmacia, Uppsala, Sweden) was added to the whole blood ( $1: 2$ dilution), and the sample was inverted several times and subjected to $1 \mathrm{~g}$ velocity sedimentation for 1 hour. The leukocyte-containing layer was removed and the neutrophils separated by Ficoll-Hypaque (Sigma Chemical Co., St. Louis, Mo.) density centrifugation. ${ }^{12}$ After the sample was washed, integrin expression was detected with use of a double-antibody technique. Ten microliters of the first antibody, anti-CD11b antibody (Becton-Dickinson, San Jose, Calif.) or the isotype control was added and the sample incubated for 30 minutes. After the sample was washed, $10 \mu$ of the second antibody, a
Table I. Age, weight, and duration of $C P B$ for groups $A, B$, and $C$

\begin{tabular}{llcc}
\hline & Age $(\mathrm{yr})$ & $\begin{array}{c}\text { Weight } \\
(\mathrm{kg})\end{array}$ & $\begin{array}{c}\text { CPB } \\
\text { duration } \\
(\text { min })\end{array}$ \\
\hline Group A & $66 \pm 3$ & $76.3 \pm 3$ & $73 \pm 3.1$ \\
Group B & $62 \pm 3.5$ & $81.5 \pm 4$ & $75.5 \pm 5$ \\
Group C & $61 \pm 4.5$ & $80.5 \pm 3.6$ & $79.4 \pm 5$ \\
\hline
\end{tabular}

Values given as mean plus or minus the standard deviation. No significant differences were found between groups in any variable measured.

fluorescein isothiocyanate conjugate of goat antimouse immunoglobulin (Becton-Dickinson), was added to the suspension and incubated for at least 30 minutes. The fluorescein-conjugated second antibody allows for a fluorescence-activated cell sorter (FACScan, Becton-Dickinson) to quantify the surface expression of each neutrophil surface integrin as described by Ledbetter and Herzenberg. ${ }^{13}$ Flow cytometry data analysis (FACScan) was done with Lysis II software (Becton-Dickinson) and the data were expressed as mean fluorescence intensity on a linear scale. Mean fluorescence intensity was then used to evaluate differences between times and the three groups.

TNF plasma levels were determined at the same time intervals used for neutrophil CD11b integrin expression. Arterial blood for TNF- $\alpha$ levels was collected in sterile 20 $\mathrm{ml}$ syringes, spun immediately at $2000 \times g$ for 15 minutes, frozen at $-80^{\circ} \mathrm{C}$ and batched. TNF- $\alpha$ was quantified by use of a "sandwich" enzyme-linked immunosorbent assay using specific monoclonal antibodies (Quantikine HS, R \& D Systems, Minneapolis, Minn.) after plasma thawing and extraction were accomplished as described by others. ${ }^{14}$ A repeated-measures analysis of variance was done to distinguish within-group differences over time, and $t$ tests were done to evaluate differences at the same periods between groups; $p$ values of 0.05 or less were considered significant.

\section{Results}

There were no significant differences between groups in age, weight, or CPB duration (Table I).

CD11b. Group A demonstrated significant $(p<$ 0.05 ) increases in mean fluorescence intensity at times 2 and 3 when results were compared with those of the same group baseline. Groups B and C demonstrated no significant changes at any time. When findings of group $A$ were compared with those of groups $\mathrm{B}$ and $\mathrm{C}$, a significant $(p<0.05)$ increase in mean fluorescence intensity was found to occur at times 2 and 3 (Fig. 1).

TNF- $\alpha$. Group A demonstrated a significant increase $(p<0.05)$ in TNF- $\alpha$ plasma levels in period 3 as compared with the level of the same group baseline. Groups B and C demonstrated no significant changes at any time. When findings in group $\mathrm{A}$ were compared with those of groups B and C, a 


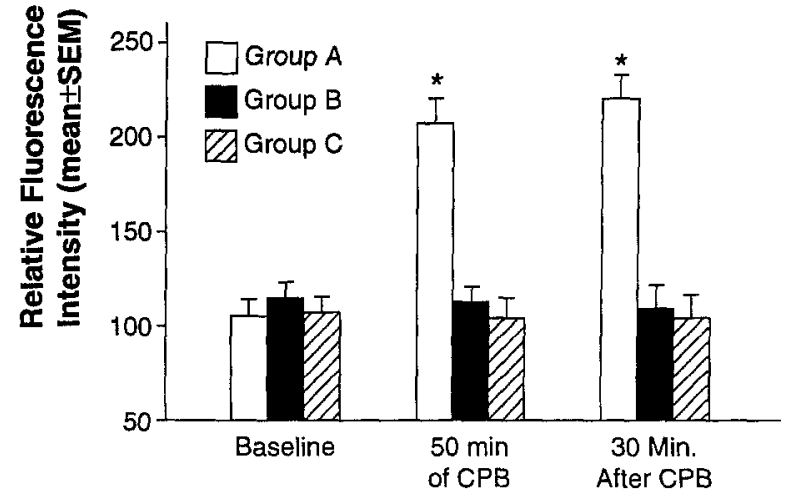

Fig. 1. Mean fluorescence intensity of CD11b neutrophil integrin for groups $\mathrm{A}, \mathrm{B}$, and $\mathrm{C}$ at baseline, after 50minute duration of $\mathrm{CPB}$, and 30 minutes after $\mathrm{CPB}$ termination. SEM, Standard error of mean. ${ }^{*} p<0.05$ compared with baseline (group A) and compared with same times in groups $\mathrm{B}$ and $\mathrm{C}$.

significant $(p<0.05)$ increase in TNF plasma levels was found to occur at period 3 (Fig. 2).

\section{Discussion}

Originally used in the treatment of acute pancreatitis, ${ }^{15}$ aprotinin is now used primarily to reduce blood loss during cardiac operations. ${ }^{16}$ The hemostatic efficacy of aprotinin has been established with the most common dosing protocol of a $2 \times 10^{6} \mathrm{KIU}$ $(280 \mathrm{mg})$ loading dose with a $2 \times 10^{6} \mathrm{KIU}(280 \mathrm{mg})$ pump prime dose and a continuous infusion of $500,000 \mathrm{KIU} / \mathrm{hr}^{16,17}$ Such high-dose protocols resulting in plasma levels of more than $250 \mathrm{KIU} \cdot \mathrm{ml}^{-1}$ have been shown to be no more effective in reducing post-CPB blood loss than low-dose (as used in this study) protocols resulting in plasma concentrations of $125 \mathrm{KIU} \cdot \mathrm{ml}^{-1}$. 18, 19 Reduced fibrin degration products, $\alpha_{2}$-plasmin inhibitor levels, ${ }^{20}$ and improved platelet aggregation ${ }^{21}$ have been reported with low-dose protocols during CPB in human beings, whereas high-dose aprotinin inhibits neutrophil elastase release during simulated extracorporeal perfusion. ${ }^{22}$ Aprotinin has been reported to inhibit interleukin-6 release during $\mathrm{CPB}^{11}$ and improves neutrophil chemotaxis after aortic operations $^{23}$ in human beings, and, in animal models, reduces extravascular water content in brain, heart, and lung after circulatory arrest. ${ }^{24}$ Other animal studies demonstrate aprotinin blunts the circulatory consequences of endotoxin exposure. ${ }^{10,25}$ Our data demonstrate aprotinin inhibits systemic TNF release and subsequent neutrophil CD11b upregulation,

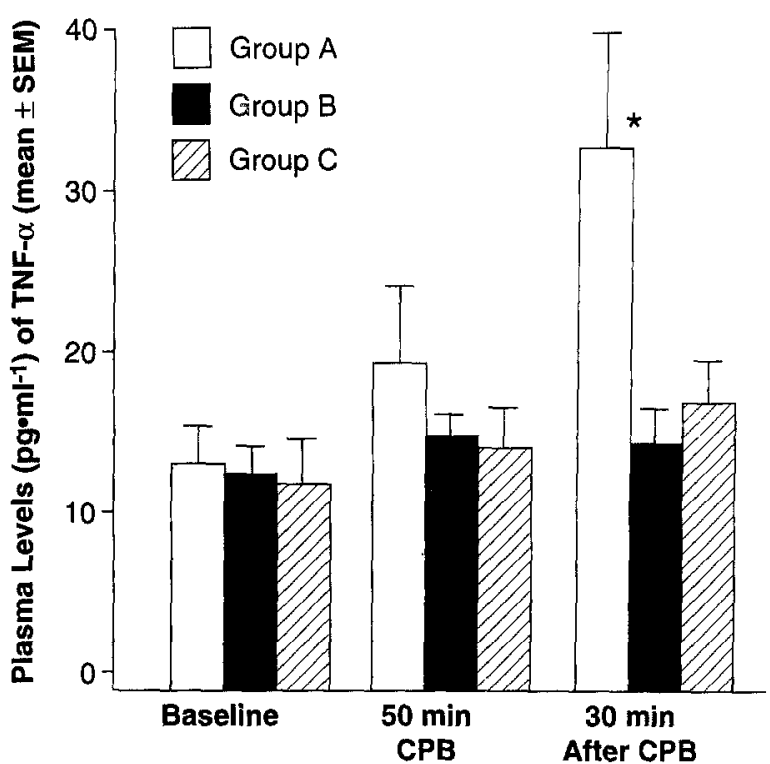

Fig. 2. Plasma levels of TNF for groups $A, B$, and $C$ at baseline, after 50-minute duration of CPB, and 30 minutes after CPB termination. SEM, standard error of mean. * $p$ $<0.05$ compared with baseline (group A) and compared with same times in groups B and C.

which is in further support of an antiinflammatory effect of aprotinin during CPB in human beings.

Neutrophil surface adhesive protein (or integrin) CD11b and CD11a and CD11c make up the leukocyte integrins; each shares a common $\beta$ subunit (CD18) but has distinct $\alpha$ subunits. ${ }^{26}$ Activated neutrophils express primarily $\mathrm{CD}_{11} \mathrm{~b}^{26}$ and only CD11b has been shown to be upregulated during CPB. ${ }^{9,27}$ Cytokines, including TNF, rapidly ( 2 to 4 minutes) $)^{2,28}$ and permanently ${ }^{29}$ upregulate CD11b expression. Neutrophil integrin CD11b is known to be the primary integrin involved in neutrophil adherence during reperfusion injury in myocardium ${ }^{30}$ and lung ${ }^{6}$ after CPB.

Glucocorticoids are known to blunt CPB-induced TNF release ${ }^{8}$ but not CPB-induced endotoxemia. ${ }^{31}$ Glucocorticoids are also known to downregulate TNF production in human subjects after endotoxin infusions $^{32}$ and to inhibit the expression of the endothelial adhesion receptor (intercellular adhesion molecule 1$)^{33}$ to which neutrophil integrin CD11b adheres., ${ }^{3,4}$ In addition, glucocorticoids are known to block CPB-induced neutrophil CD11b expression, presumably by blunting TNF release, ${ }^{9}$ and to reduce endotoxin-stimulated alveolar macrophage TNF release. ${ }^{34}$ Although, few data exist that demonstrate an effect of aprotinin on cytokine gen- 
eration or activity, TNF-induced cytotoxicity of murine fibroblasts has been reported to be inhibited by aprotinin. ${ }^{35}$ This study is the first report of the effects of aprotinin on reducing TNF release during CPB in human beings.

In summary, low-dose aprotinin administered before and during $\mathrm{CPB}$ in human beings reduces systemic TNF release and subsequent neutrophil CD11b upregulation. This effect of aprotinin is similar to that found in a comparable group of patients given a glucocorticoid (methylprednisolone) only. These data demonstrate aprotinin to have an antiinflammatory effect during CPB in human beings.

Statistical analysis was done, in part, by Elizabeth Ruby, MS, Department of Preventive and Societal Medicine, University of Nebraska Medical Center.

\section{REFERENCES}

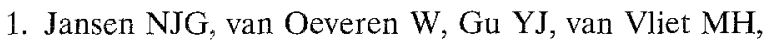
Eijsman L, Wildevuur CRH. Endotoxin release and tumor necrosis factor formation during cardiopulmonary bypass. Ann Thorac Surg 1992;54:744-8.

2. Hughes BJ, Hollers JC, Crockett-Torabi E, Smith $\mathrm{CW}$. Recruitment of CD11b/CD18 to the neutrophil surface and adherence-dependent cell locomotion. J Clin Invest 1992;90:1687-96.

3. Springer TA. Adhesion receptors of the immune system. Nature 1990;346:425-33.

4. Osborn L. Leukocyte adhesion to endothelium in inflammation. Cell 1990;62:3-6.

5. Dreyer WJ, Michael LH, Njuyen T, et al. Neutrophilmediated pulmonary injury in a canine model of cardiopulmonary bypass: evidence for a CD18 dependent mechanism. Circulation 1992;86(Suppl):I629.

6. Gillinov AM, Redmond JM, Zehr KJ, et al. Inhibition of neutrophil adhesion during cardiopulmonary bypass. Ann Thorac Surg 1994;57:126-33.

7. Byrne JG, Smith WJ, Murphy MP, Couper GS, Appleyard RF, Cohn LH. Complete prevention of myocardial stunning, contracture, low-reflow, and edema after heart transplantation by blocking neutrophil adhesion molecules during reperfusion. J THORAC Cardiovasc Surg 1992;104:1589-96.

8. Jansen NJG, van Oeveren W, Broek LVD, et al. Inhibition by dexamethasone of the reperfusion phenomena in cardiopulmonary bypass. J THORAC CARDIOVASC SURG 1991;102:515-25.

9. Hill GE, Alonso A, Thiele GM, Robbins RA. Glucocorticoids blunt neutrophil CD11b surface glycoprotein upregulation during cardiopulmonary bypass in humans. Anesth Analg 1994;79:23-7.

10. Svartholm E, Haglund U, Ljungberg J, Hedner U.
Influence of aprotinin, a protease inhibitor, on porcine E. coli shock. Acta Chir Scand 1989;155:7-13.

11. Whitten CW, Latson TW, Allison PM, et al. Does aprotinin inhibit cardiopulmonary bypass-induced inflammation? Anesthesiology 1992;77:A266.

12. Böyum A. Isolation of mononuclear cells and granulocytes from human peripheral blood. Scand $\mathrm{J}$ Clin Lab Invest 1968;21(Suppl 97):77-89.

13. Ledbetter JA, Herzenberg LA. Xenogeneic monoclonal antibodies to mouse lymphoid differentiation antigen. Immunol Rev 1979;57:63-90.

14. Van der Meer JW, Enders S, Lonneman G, et al. Concentrations of immunoreactive human tumor necrosis factor alpha produced by human mononuclear cells in vitro. J Leukoc Biol 1988;43:16-23.

15. Trapnell JE, Rigby CC, Talbot CH, Duncan EHL. A controlled trial of Trasylol in the treatment of acute pancreatitis. Br J Surg 1974;61:177-82.

16. Bidstrup BP, Royston D, Sapsford RN, Taylor KM. Reduction in blood loss and blood use after cardiopulmonary bypass with high-dose aprotinin (Trasylol). J ThoraC CARDiovasC SuRg 1989;97:364-72.

17. Royston D. Aprotinin prevents bleeding and has effects on platelets and fibrinolysis. J Cardiothorac Vasc Anesth 1991;5(Suppl 1):18-23.

18. Hardy JF, Desroches J. Natural and synthetic antifibrinolytics in cardiac surgery. Can J Anaesth 1992;39: $353-65$.

19. Schönberger J, Everts P, Ercan H, et al. Low-dose aprotinin in internal mammary artery bypass operations contributes to important blood savings. Ann Thorac Surg 1992;54:1172-6.

20. Kawasuji M, Ueyama K, Sakakibara N, et al. Effect of low-dose aprotinin on coagulation and fibrinolysis in cardiopulmonary bypass. Ann Thorac Surg 1993;55: 1205-9.

21. Lavec J, Raviv Z, Smolinsky A, et al. Platelet protection by low-dose aprotinin in cardiopulmonary bypass: electron microscopic study. Ann Thorac Surg 1993;55: 114-9.

22. Wachtfogel YT, Kucich U, Hack CE, et al. Aprotinin inhibits the contact, neutrophil, and platelet activation systems during simulated extracorporeal perfusion. J Thorac Cardiovasc Surg 1993;106:1-9.

23. Lord RA, Roath OS, Thompson JF, Chant ADB, Francis JL. Effect of aprotinin on neutrophil function after major vascular surgery. Br J Surg 1992;79:51721.

24. Aoki M, Jonas RA, Nomura F, et al. Effects of aprotinin on acute recovery of cerebral metabolism in piglets after hypothermic circulatory arrest. Ann Thorac Surg 1994;58:146-53.

25. Hughes B, Parratt JR. The effects of the protease inhibitor, aprotinin, on the course of shock induced by endotoxin in cats. Br J. Pharmacol 1985;86:399-403.

26. Arnaout MA. Structure and function of the leukocyte 
adhesion molecule CD11/CD18. Blood 1990;75:103750.

27. Gillinov AM, Bator JM, Zehr KJ, et al. Neutrophil adhesion molecule expression during cardiopulmonary bypass with bubble and membrane oxygenator. Ann Thorac Surg 1993;56:847-53.

28. Osborn L. Leukocyte adhesion to endothelium in inflammation. Cell 1990;62:3-6.

29. Springer TA. Adhesion receptors of the immune system. Nature 1990;346:425-34.

30. Wilson I, Gillinov AM, Curtis WE, et al. Inhibition of neutrophil adherence improves postischemic ventricular performance of the neonatal heart. Circulation 1993;88:372-9.

31. Andersen LW, Baek L, Thomsen BS, Rasmussen JP. Effect of methylprednisolone on endotoxemia and complement activation during cardiac surgery. J Cardiothorac Anesth 1989;3:544-9.

32. Barber AE, Coyle SM, Fong $\mathrm{Y}$, et al. Impact of hypercortisolemia on the metabolic and hormonal responses to endotoxin in humans. Surg Forum 1990; 41:74-7.

33. Cronstein BN, Kimmel SC, Levin RI, Martiniuk F; Weissman G. A mechanism for the antiinflammatory effects of corticosteroids: the glucocorticoid receptor regulates leukocyte adhesion to endothelial cells and expression of endothelial-leukocyte adhesion molecule 1 and intercellular adhesion molecule 1. Proc Natl Acad Sci USA 1992;89:9991-5.

34. Huang ZB, Eden E. Effect of corticosteroids on IL $\beta$ and TNF- $\alpha$ release by alveolar macrophages from patients with AIDS and pneumocystic pneumonia. Chest 1993;104:751-5.

35. Hunyadi J, Kenderessy AS, Duda E, et al. Plateletactivating factor antagonists (BN 52021 and BN 50730) inhibit tumor necrosis factor-alpha-mediated cytotoxicity on murine L929 tumor cells. Mol Immunol 1993;30:517-9.

\section{1-800-55-MOSBY}

This number links you to the full text of articles published in over 25,000 journals, including all Mosby journals. MOSBY Document Express $^{3}$, a rapid response information retrieval service, provides quick turnaround, 24-hour availability, and speedy delivery methods. For inquiries and pricing information, call our toll-free, 24-hour order line: 1-800-55-MOSBY; outside the United States: 415-259-5046; fax: 415-259-5019; E-mail: mosbyexp@class.org. 